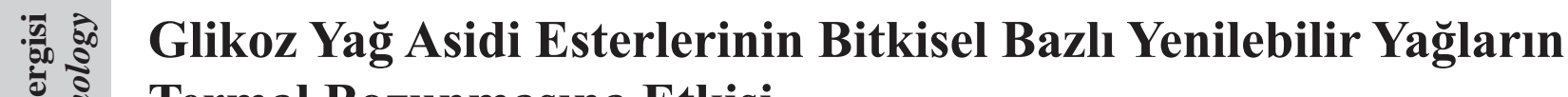 Termal Bozunmasına Etkisi

\author{
Neslihan ŞAKİ ${ }^{1}$, Mustafa AKIN ${ }^{1}$
} \\ ÖZET: Çalışma, 15 gün boyunca $60^{\circ} \mathrm{C}^{\prime}$ de hızlandırılmış depolama testi altında standart antioksidanlar ve glukoz yağ asidi esterleri eklenmesinin ayçiçeği, mısır ve zeytinyağının termal stabilitelerini nasıl etkilediğiyle ilgili sonuçları sunmaktadır. Çalışmada glikoz oleat ve glikoz laurat sentezlenerek karakterize edildi. Zeytin, ayçiçek ve mısır yağının yağ asidi bileşenleri GC kullanılarak belirlendi ve bütün numunelerde peroksit değeri, serbest yağ asidi oranı ve fenol içeriği saptandı. Yüksek oleik asit içeriği yenilebilir yağlarda termal bozunmayı artırdı. Glikoz oleat ve glikoz laurat bitkisel bazlı yenebilir yağlar için bir termal oksidasyon önleyici olarak etkili olurken, glikoz oleat her türlü yağ için glikoz laurattan daha iyi antioksidan özellik gösterdi.
}

Anahtar Kelimeler: Bozunma, yenilebilir yağlar, glikoz esterleri, oksidasyon.

\section{Effect of Glucose Fatty Acid Esters on the Thermal Degradation of Vegetable Based Edible Oils}

\begin{abstract}
The study presents the results on the thermal stability of the sunflower, corn and olive oil with addition of standard antioxidants and glucose fatty acid esters under accelerated storage test at $60^{\circ} \mathrm{C}$ for 15 days. During the work, glucose oleate and glucose laurate were synthesized and characterized. Fatty acid compositions of olive, sunflower and corn oil were determined by using GC and in all samples peroxide value, free fatty acid value and phenolic content are specified. High oleic acid content increased the thermal degradation in edible oils. Glucose oleate and glucose laurate acted as a thermal oxidation suppressor for the vegetable based edible oils and glucose oleate showed better antioxidant properties than glucose laurate for all types of oils.
\end{abstract}

Key words: Degradation, edible oils, glucose esters, oxidation.

Neslihan ŞAKİ (0000-0002-2215-1622), Mustafa AKIN (0000-0003-4268-6891), Kocaeli Üniversitesi, Fen-Edebiyat Fakültesi, Kimya Bölümü, İzmit-Kocaeli, Türkiye

Sorumlu yazar/Corresponding Author: Neslihan ŞAKİ, sakineslihan1@gmail.com 


\section{GİRIŞ̧}

Bitkilerin tanelerinden ya da tohumlarından elde edilen yağlar genelde iki önemli kısım içerir. Bunlar; protein ve yağ kısımlarıdır. Rafine bitkisel yağlara uygulanan prosesler istenmeyen maddelerle birlikte yararlı vitamin ve antioksidanlar gibi küçük bileşenleri de uzaklaştırır (Gunstone, 2000). Yenilebilir yağ kalitesi ve stabilitesi, yağın kabul edilebilirliği ve piyasa değerini etkileyen başlıca faktörlerdir. Oksidatif stabilite, yenilebilir yağların kalitesini korumak için en önemli göstergelerden biridir (Tan ve ark; 2002). Doymamış yağ asitlerinin oksidasyonu, aroma dışı bileşiklerin gelişiminin ve gıda ürünlerinin besin değerinin azalmasının başlıca nedenlerinden biridir (Hemalatha ve Ghafoorunissa, 2007). Lipitsiz radikallerin konsantrasyonu ve lipitlerdeki doğal antioksidanların miktarı, yenilebilir yağların oksidatif strese karşı stabilitesini öngörmede önemli faktörlerdir (Choe ve Min, 2005; Lee ve ark., 2007).

Bitkisel yağların pişirme sırasında maruz kaldıkları yüksek sıcaklık uygulamaları, yağın termo oksidatif bozunmasını geciktirmek için daha verimli antioksidanların kullanılmasını gerektirir. $\mathrm{Bu}$ nedenle, yenilebilir yağların rafine edilmesi sırasında ve işlenmiş gıdaların üretiminde; bütil hidroksitoluen (BHT), bütillenmiş hidroksianisol (BHA), butil hidrokinon (TBHQ) gibi sentetik antioksidanlar izin verilen seviyelerde (Awasthi, 2007; Kaitaranta, 1992) ilave edilir. Ancak, çalışmalar bu bileşiklerin insan sağlığ1 için risk oluşturduğunu ortaya koymuştur (Zhang ve ark, 2010) ve bu durum doğal antioksidanlara olan ilgiyi artırmaktadır (Akin ve ark, 2013; Zeb ve Murcovic, 2013).

Hidroperoksitler birincil oksidasyon ürünleri olup alkanlar, alkoller, aldehitler ve asitler gibi bir takım ikincil ürünler üreten, bazıları düşük eşik değerlerinde kötü koku veren kararsız bileşiklerdir. $\mathrm{Bu}$ ikincil oksidasyon ürünlerinin birçoğu son derece reaktiftirler (Yanishlieva ve Marinova, 2001) ve oksidatif zincir sürecini in vivo başlatabilirler. $\mathrm{Bu}$ durum kanser, ateroskleroz, kalp ve alerjik hastalıkların ilerlemesine katkıda bulunabilir (Simic ve Karel, 1980). Lipid peroksidasyon mekanizmas1 ve bunların gıda kalitesi üzerindeki etkileri kapsamlı olarak gözden geçirilmiştir (Frankel, 1993; Angelo, 1992).

Sebzeler pişirildiğinde daha yenilebilir ve daha sindirilebilir bir hale gelir. Bununla birlikte, 1s1 işlem, esas olarak lipit oksidasyonuna bağlı gıdaların besin değerinin kaybı ve protein fraksiyonunun bazı bileşenlerinde değişiklikler gibi istenmeyen modifikasyonlara yol açabilir. Lipit oksidasyonu özellikle, oksijen, enerji (UV/1s1) ve metallerin varlığında gerçekleşir. Yağ asitlerinin trigliseritler ve fosfolipitlere bağlı oksidasyon ürünlerinin biyolojik aktiviteleri sonucu damar sertliği başlangıcı ve ilerlemesi ile erken yaşlanma ile ilişkili bir dizi olumsuz etkileri oluşmaktadır.(Addis ve Warner, 1991; Maranesi ve ark., 2005). Ayrıca bu ürünlerin birçoğu, aterojeniklik, sitotoksisite ve enzim aktivitesinin modifikasyonları gibi önemli biyolojik etkilere de sahiptir (Erickson ve ark., 1978).

Şeker yağlı asit esterleri, düşük toksisitelerinin yanısıra kokusuz ve biyolojik olarak parçalanabilen özellikleri nedeniyle de geniş bir uygulama alanına sahip olan non-iyonik yüzey aktif maddeler olarak bilinirler (Li ve ark., 2015). Şeker esterlerinin emülgatör özellikleri (Allen ve Tao, 2002), antimikrobiyal özellikler (Zhao ve ark., 2015; Furukawa ve ark., 2010), böcek aktiviteleri (Kays ve Tang, 1997) ve yağlayıcılık özellikleri (Aoshima ve ark., 2005) birçok çalışmada araştırılmıştır. Yapılan çalışmada, şeker esterlerinin yenilebilir bitki bazlı yağların termal stabilitesi üzerindeki etkileri araştırılmış ve yenilebilir yağlarda oksidasyon önleyici olarak kullanılan sentetik moleküller yerine, doğal gıda ile direkt temasta insan sağlığına ve çevreye zararsız olan şeker yağ asidi esterlerinin kullanımı ile ilgili oldukça önemli sonuçlar elde edilmiştir.

\section{MATERYAL VE YÖNTEM}

\section{Şeker Yağ Asidi Esterlerinin Sentezi}

Glikoz ve yă asidi klorürlerin esterifikasyon reaksiyonu için, daha önce Allen ve Tao (2002) tarafından kullanılan yöntem bazı modifikasyonlar yapılarak uyguland1. Reaksiyon sonlandırıldıktan sonra oda sıcaklığına soğutularak $300 \mathrm{~mL}$ kloroform 
eklendi ve reaksiyona girmeyen şekeri ortamdan uzaklaştırmak için filtre edildi. Çözücü $80^{\circ} \mathrm{C}$ de vakumda uçurulduktan sonra kalan kısma $200 \mathrm{~mL}$ deiyonize su eklendi ve karışım ayırma hunisine alındı. Ortama $500 \mathrm{~mL}$ hekzan ilave edilerek çalkalandı ve ayırma hunisinde ayrılması beklendi. Daha sonra hekzan fazı alınıp evaporatörde uçurularak ürün elde edildi. Tüm reaksiyonlar, yürütücü olarak heksan / kloroform / metanol (8: 1: 1) ve görüntüleme ajanı olarak metanol / sülfürik asit (4: 1) kullanılarak silika jel 60 plakaları üzerinde ince tabaka kromatografisi (TLC) ile izlendi. Sentezlenen moleküllerin FT-IR spektrumları da BRUKER TENSOR 27 spektrometre kullanılarak elde edildi.

\section{Yağ Numunelerinin Hazırlanması}

Test edilecek her bir bitkisel yağ içerisinde ayrı ayrı glikoz oleat ve glikoz laurat $50 \mathrm{mg} \mathrm{mL}^{-1}$ olacak şekilde $40^{\circ} \mathrm{C}$ de çözüldü. Pozitif kontrol olarak da her bir yağ $50 \mathrm{mg} \mathrm{mL}^{-1}$ konsantrasyonda BHT'de $40^{\circ} \mathrm{C}$ de çözüldü ve bir grup ta hiçbir antioksidan madde eklenmeden hazırlandı. Her üç grup ta $60^{\circ} \mathrm{C}$ ye ayarlanmış etüvde 15 gün boyunca depolama testine tabi tutuldu ve $0,1,3,5,7$ ve 15 . günlerde alınan numunelere ilgili testler uygulandı (Ghafoorunissa, 2007).

\section{GC Analizi}

Yağ asitleri bileşimi, susuz metanol içinde $2 \mathrm{~N} \mathrm{KOH}$ ile yağ asidi metil esterlerine (FAME) türevlendirildikten sonra gaz kromatografisi (GCShimadzu QP) ile elde edildi. Bir alev iyonizasyon detektörü (FID), SP2380 kapiler kolon $(50 \mathrm{~m} \mathrm{x}$ $0,25 \mathrm{~mm}$ boyutlarında) İD.; $0,25 \mu \mathrm{m}$ film kalınlığ 1 kullanıldı. Firın sıcaklığ $140{ }^{\circ} \mathrm{C}$ 'de 4 dakika ve $220{ }^{\circ} \mathrm{C}$ 'de 15 dakika tutma ile $4{ }^{\circ} \mathrm{C} \min ^{-1}$ 'de 40 ila $220^{\circ} \mathrm{C}$ 'de programland1. Analiz boyunca enjektör ve ara yüz sıcaklıkları $250^{\circ} \mathrm{C}$ ve iyon kaynağ sıcaklığ 1 $200{ }^{\circ} \mathrm{C}$ idi. Bileşiklerin tutulma endeksleri (RI), n-alkanların (C8.C24) bir karışımına göre hesaplandı. Piklerin tanımları, tutma sürelerini saf standart bileşenlerinkilerle karşılaştırabilmek için 37 Bileşen
FAME Mix (Supelco) harici standart kullanıldı (Molkentin, 2009).

\section{Toplam Fenol İçeriği}

$5 \mathrm{~g}$ yağ, heksan $(10 \mathrm{~mL})$ içerisinde çözüldü ve polar bileşimler, bir ayırma hunisi kullanılarak sulu \% 60 metanol $(3 \times 20 \mathrm{~mL})$ içine özümlendi. Her ekstraksiyon ikişer kez tekrarlandı. Daha sonra sulu fraksiyonlar birleştirildi, heksan $(20 \mathrm{~mL})$ ile yıkand1, süzüldü ve vakum altında $\sim 35^{\circ} \mathrm{C}$ 'de buharlaştırıldı. Tortu, metanol $(5 \mathrm{~mL})$ içinde çözüldü ve karanlıkta -20 ${ }^{\circ} \mathrm{C}$ 'de kapaklı bir şişede saklandı. Metanolik ekstraktın bir alikotu $(0,2 \mathrm{~mL})$, azot altında kuruyana kadar buharlaştırıldı, su içinde yeniden çözüldü ve önce seyreltilmiş (1:10) Folin-Ciocalteu reaktifi (1 $\mathrm{mL}), 3$ dakika sonra da $\% 7.5$ sodyum karbonat $(0,8$ $\mathrm{mL}$ ) eklendi. 30 dakika sonra $765 \mathrm{~nm}$ 'de (Optimizer POP UV/Vis spektrometresi) absorbans ölçümü yapıldı ve kalibrasyon için de Gallic asit kullanıldı. Yinelenen analizlerin sonuçları GAE (milyonda GAE başına parça) olarak ifade edildi (Koski ve ark., 2003).

\section{Peroksit Değerleri}

Peroksit değeri, peroksit grubu biçimindeki $\mathrm{O}_{2}$ molekülünün yağ molekülüne nüfuz ettiği ve yağlardaki oksidatif değişimin başlangıcını tanımlamak için kullanılır. Peroksit değeri yöntemi; hem Amerikan Petrolü Kimyacı Topluluğu (AOCS) hem de Analitik Kimyacıları Derneği'nde (AOAC), 965,33(AOAC) veya Cd-8b(AOCS) yöntemleri olarak (Lee ve ark. 2007; AOCS, 1993) bilinmektedir. Çalışmamızda yă̆ örneklerinin peroksit değerleri otomatik (Easy CI titrator- Mettler Toledo) titratör kullanılarak belirlenmiştir.

\section{Serbest Yağ Asidi İçeriği}

$1 \mathrm{~g}$ yağ, $50 \mathrm{ml}$ etanol / dietil eter $(1: 1 \mathrm{v} / \mathrm{v})$ ile seyreltildi. İndikatör olarak fenolftalein eklendi ve örnek 0,1 M KOH ile titre edildi (Von der Haar ve ark., 2015). Asit sayısı (AN), aşağıda verilen formül ile hesapland 1

$$
\mathrm{AN}(\mathrm{mg} / \mathrm{g})=\frac{\mathrm{M}(\mathrm{KOH})(\mathrm{mg} / \mathrm{mmol}) \times \mathrm{c}(\mathrm{KOH})(\mathrm{mmol} / \mathrm{ml}) \times \mathrm{V}(\mathrm{KOH})(\mathrm{ml})}{\mathrm{m}(\mathrm{oil})(\mathrm{g})}
$$


Hesaplanan AN'nın SYA (serbest yağ asidi)'nın kütlesel yüzdesi içindeki dönüşümü aşağıdaki formülle verildi:

$$
\mathrm{FFA}[\%(\mathrm{w} / \mathrm{w})]=\frac{\mathrm{M}(\mathrm{FFA})(\mathrm{mg} / \mathrm{mmol}) \times \mathrm{AN}(\mathrm{mg} / \mathrm{g}) \times 0.1}{\mathrm{M}(\mathrm{KOH})(\mathrm{mg} / \mathrm{mmol})}
$$

\section{Kimyasal ve Fiziksel Özelliklerin Belirlenmesi}

Hızlandırılmış depolama testi öncesinde ve sonrasında viskozite ölçümleri ASTM D445-97'ye göre yapıldı. Ölçümler $40{ }^{\circ} \mathrm{C}$ viskozite banyosunda

\section{BULGULAR VE TARTIŞMA}

\section{Şeker Yağ Asidi Esterlerinin Karakterizasyonu}

Elde edilen esterlerin yapıları FT-IR kullanılarak aydınlatıldı. Şeker ile reaksiyona giren yağ asidi klorit'lerin reaksiyon öncesi ve sonrası spektrumları
TANAKA AKV 202 oto kinematik viskozimetre ile yapılarak renk değişimleri ASTM D 6045 yöntemine göre Lovibond, PFX-i serisi spektrokolorimetre kullanılarak ölçüldü.

alınarak yapıdaki değişim açıklanmıştır (Şekil 1). Spektrumlarda da görüldüğü gibi esterleşme sırasında oluşan fonksiyonel gruplara ait pikler spektrumda mevcuttur. Özellikle $1000-1500 \mathrm{~cm}^{-1}$ aralığında oluşan pikler ester oluşumunu doğrulamaktadır.

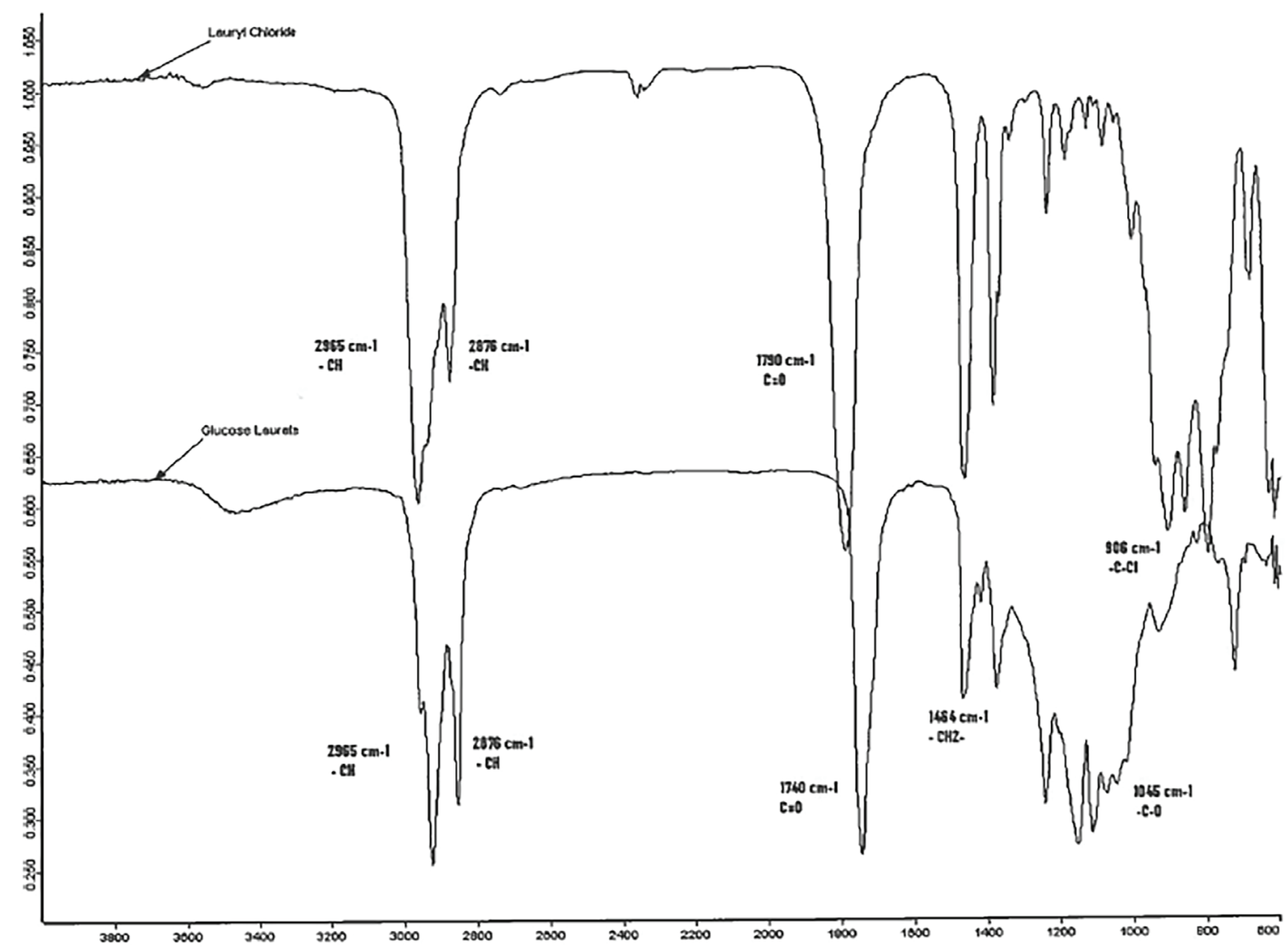




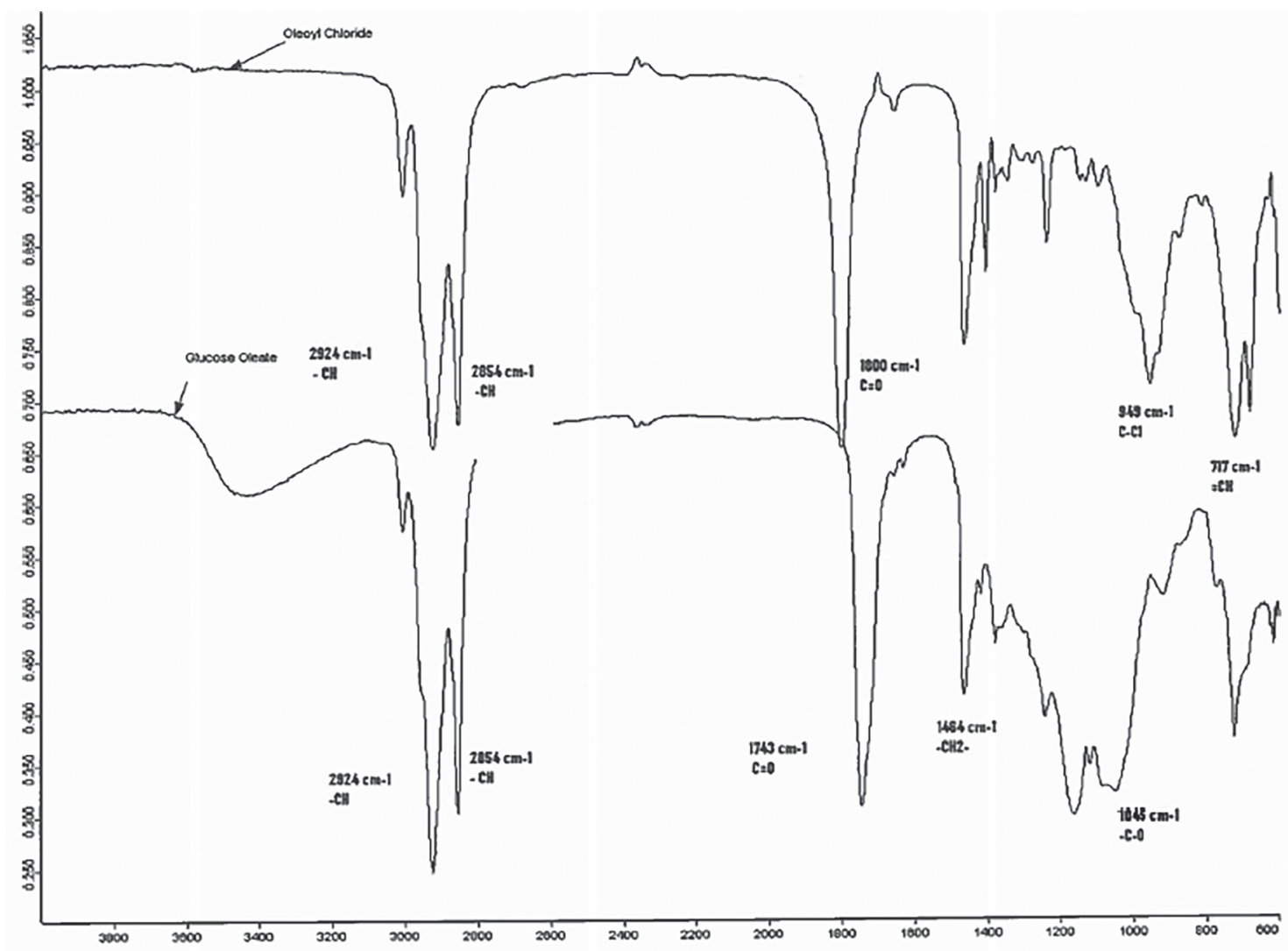

Şekil 1. Glikoz laurat (üst) ve Glikoz oleat (alt) FT-IR spektrumları.

\section{GC Analizi}

Mısır yağı, ayçiçek yağı ve zeytinyağının GC analiz sonuçlarına göre; metil ester olarak beş yağ asidi tespit edildi. Doymamış yağ asitlerinin içeriği her üç örnekte de doymuş yağ asitlerinden daha yüksekti. Doymamış yağ asitlerinin oranı ayçiçek yağ 1 için 87,22 , mısır yağ1 için 83,84 ve zeytinyağ için 79,12 ; doymuş yağ asitlerinin içeriği ise ayçiçek yağ 1 için 9,77 , mısır yağ için 13,24 ve zeytinyağ 1 için 15,75 olarak bulundu.

Yenilebilir yağların bileşimi hakkında yayınlanan makaleler de incelenmiştir. Brezilya ayçiçeği yağının kimyasal bileşiminin araştırıldığ çalışmada, başlıca yağ asitleri olarak oleik asit (\% 20-25) ve linoleik asit (\% 62-69) (Rosa ve ark., 2009) bulunmuştur. Bulunan sonuçların linoleik asit için \% 50,85 ve oleik asit için \% 36,22 olan sonuçlarımıza yakın olduğu görülmüştür. Bir diğer çalışmada, Sayali-Tunus zeytinyăg 1 kantitatif karakterizasyonu sonuçları oleik asit $(\% 77,4)$ ve triolein $(\% 47,4)$ baskın gliseridik bileşenleri (Sakouhi ve ark., 2010) olduğunu göstermiştir. Zeytinyağ $\breve{1}_{1}$ analizimizde \% 69,01 oranında oleik asit içeriği ile benzer sonuçlar elde edilmiştir. (Çizelge 1).

Çizelge 1. Bitkisel yağların yağ asidi içerikleri

\begin{tabular}{|l|l|c|c|c|}
\cline { 3 - 5 } \multicolumn{2}{c|}{} & \multicolumn{3}{c|}{$\%$} \\
\hline Yağ asidi & & Ayçiçek yağı & Mısır yağı & Zeytin yağı \\
\hline Palmitik asit & C16:0 & 6,62 & 11,15 & 0,79 \\
\hline Palmitoleik asit & C16:1 & 0,15 & 0,11 & 2,75 \\
\hline Stearik asit & C18:0 & 3,15 & 32,6 & 69,01 \\
\hline Oleik asit & C18:1,9c & 36,22 & 0,8 & 2,3 \\
\hline Oleik asit & C18:1,9t & 1,02 & 51,13 & 10,11 \\
\hline Linoleik asit & $\mathrm{C} 18: 2$ & 50,85 & & \\
\hline
\end{tabular}




\section{Toplam Fenol İçeriği}

Toplam fenolik bileşik miktarı, BHT içeren numuneler için önemli ölçüde değişiklik göstermedi. Kontrol numuneleri, tüm yenilebilir yağlar için toplam fenollerin en yüksek azalmasını gösterdi. Ayçiçeği yağı GO (glikoz oleat) ve GL (glikoz laurat) içeren numuneler için fenol içeriği test süresi arttıkça azaldı, GO içeren örneklerin fenol içeriği 38,87 ila 21,14 mgGAE / gr arasında değişirken GL içeren örneklerin fenol içeriği 34,25 ila 16,84 mgGAE / g arasındaydı.
Mısır yağı GO ve GL içeren örneklerin fenol içerikleri sırasıyla 39,26 ila 26,02 mgGAE / g ve 39,59 ile $25 \mathrm{mgGAE} / \mathrm{g}$ arasında değişim gösterdi. Zeytinyağ GO ve GL içeren numuneler içinse fenol içerikleri sirasiyla 36,214 ila $27,87 \mathrm{mgGAE}$ / g ve 35,76 ila 13,72 mgGAE / g arasında bulundu (Şekil 2).

Şeker esterlerinin yenilebilir yağların oksidasyonu üzerindeki etkileri BHT ile karşılaştırıldığında, hem GO hem de GL'nin toplam fenol içeriğinin antiproliferatif etkisi olduğu söylenebilir.

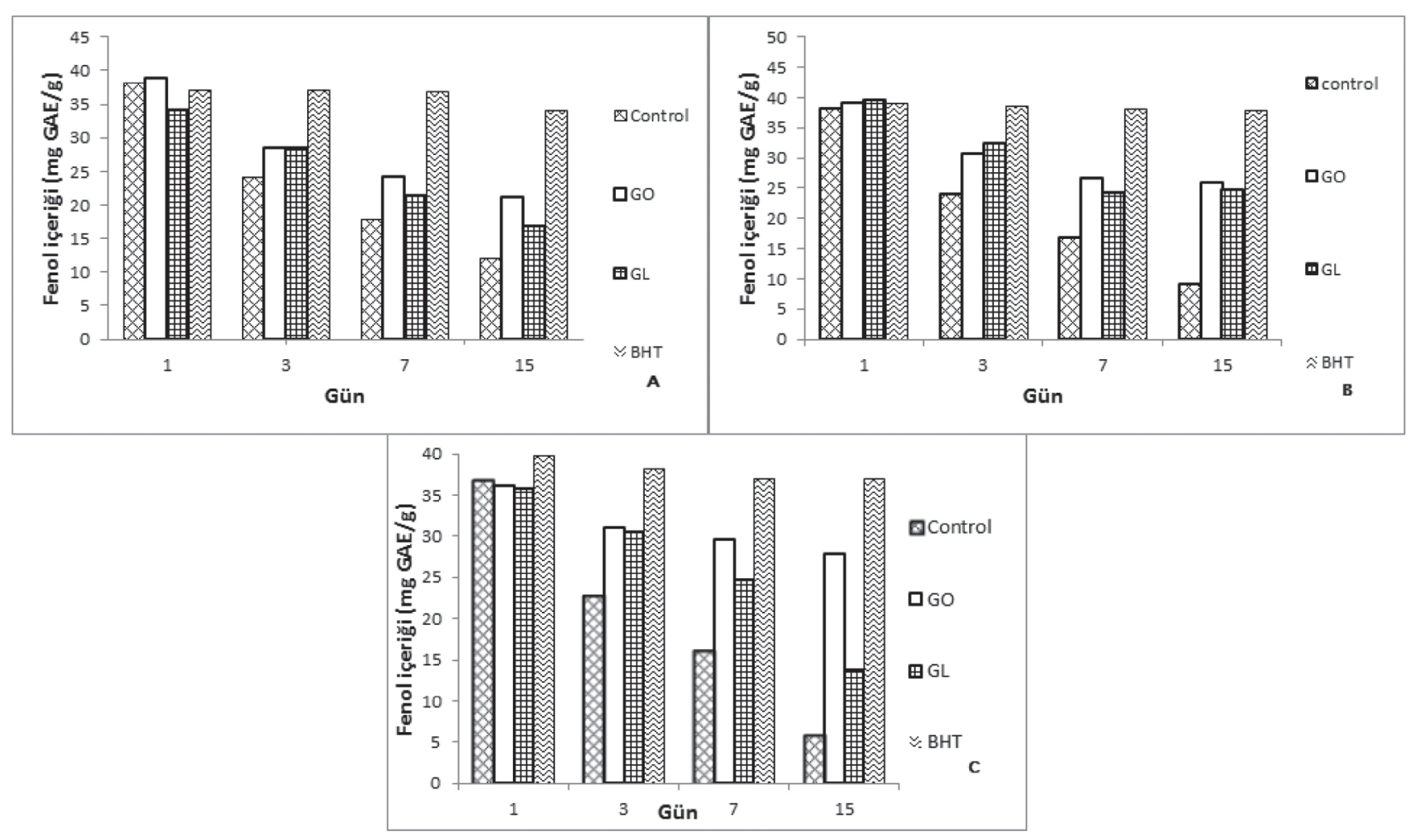

Şekil 2. Toplam fenol içerikleri, A) Ayçiçek, B) Mısır, C) Zeytinyağı (mgGAE/g).

\section{Peroksit Değerleri}

Beklendiği gibi kontrol örnekleri depolama testinden sonra en yüksek peroksit değerine ulaştı. Kontrol örneklerinde en yüksek peroksit değerleri olarak zeytinyağ için 19,21 meq / kg; ayçiçek yağ1 için, $18,67 \mathrm{meq} / \mathrm{kg}$ ve mısır yağ 1 için $14,76 \mathrm{meq} / \mathrm{kg}$ bulundu. GO içeren numuneler, tüm yenebilir yağlar için GL içeren numunelerden daha iyi oksidasyon önleyici özellikler gösterdi. GO, tüm yenilebilir yağ örneklerinde BHT kadar etkiliydi. En yüksek peroksit değerinin zeytinyağında görülmesini bu yağın en yüksek oranda doymamış yağ asidi içermesi ile açıklamak mümkündür. Yüksek doymamışlık seviyesinin lipit oksidasyonuna neden olduğu Silva and Jorge, (2012) tarafından ortaya konmuştur. (Şekil 4). GO'nun GL'den daha iyi inhibisyon etkisi göstermesi ise yapısındaki yağ asidi zincir uzunluğunun daha fazla olması ile açıklanabilir. 


\section{Serbest Yağ Asidi Değerleri}

Tüm kontrol örneklerinde, ilk günün sonunda SYA değerleri için hızlı bir artış gözlendi. Zeytinyağı kontrol numunesi, yüksek doymamış yağ asidi içeriği nedeniyle 15. günün sonunda en yüksek SYA değerine ulaştı. GO, GL ve BHT içeren yağlar, 7. güne kadar tüm yenebilir yağ örnekleri için benzer SYA içeriği gösterdi. GL içeren mısır ve zeytinyağı numunelerinin SYA değerleri 15. günde hızla artarken ayçiçek yağında önemli bir değişiklik gözlenmedi (Şekil 3).

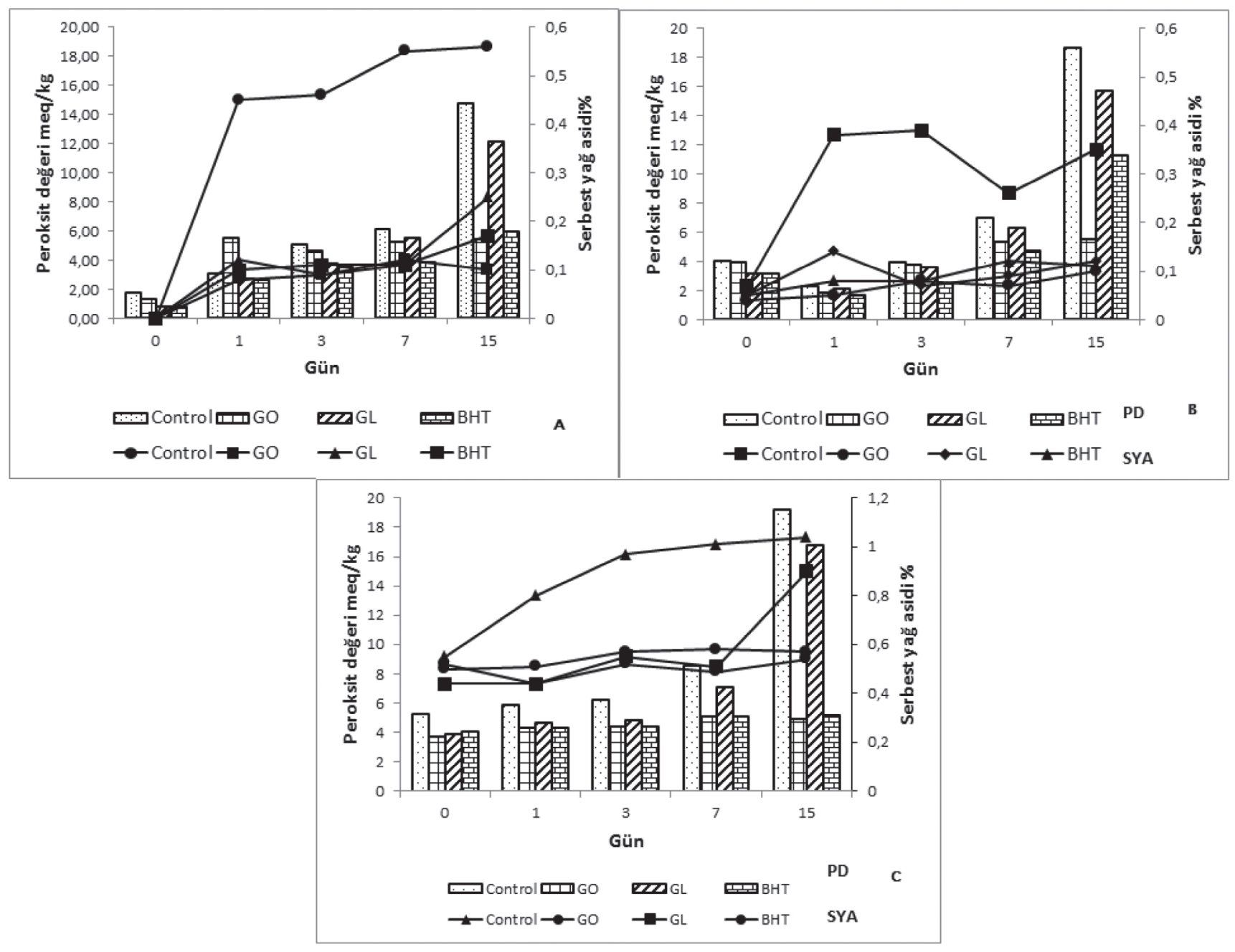

Şekil 3. Depolama süresince Serbest yağ asidi ve peroksit değerleri. A) Ayçiçek, B) Mısır, C) Zeytinyağ1

\section{Kimyasal ve Fiziksel Özellikler}

Hızlandırılmış depolama testi sırasında alınan örnek, yenilebilir yağların renk ve viskozite değişikliklerinin belirlenmesi için test edildi. En yüksek renk değişimi zeytinyağı, ayçiçeği ve mısır yağ ${ }_{1}$ kontrol örneklerinde tespit edildi. GO içeren numuneler, GL içeren numunelere kıyasla önemli ölçüde renk değişimi göstermemiştir. $40{ }^{\circ} \mathrm{C}$ deki viskozite değerlerindeki değişim incelendiğinde ise, ayçiçek yağında en yüksek değişim 3,98 cSt ile GL içeren numunede görüldü. Mısır yağı için en yüksek değişim 1,87 cSt ile GL içeren numunede, zeytinyağ 1 için ise 4,63 cSt ile GL içeren numunede tespit edilmiştir.(Çizelge 2). 


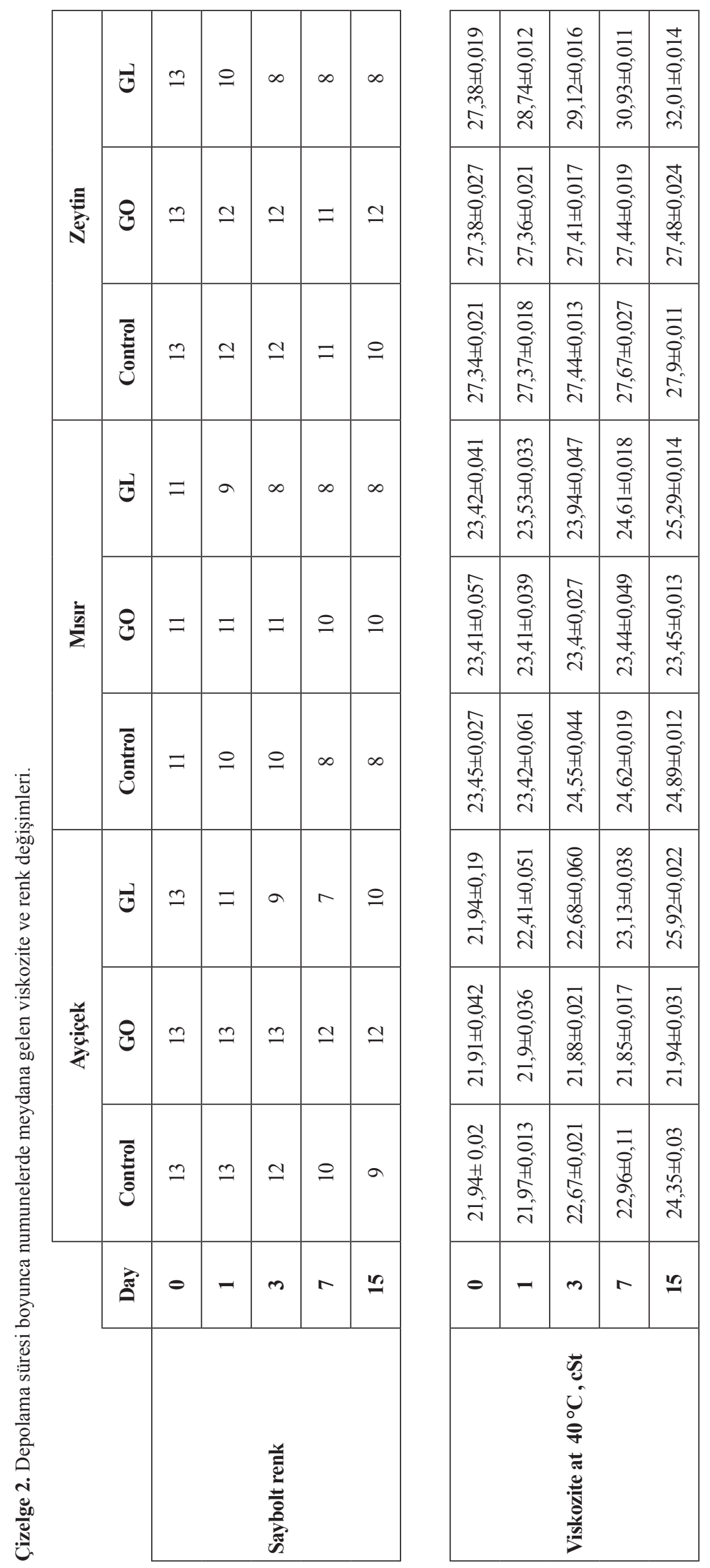




\section{SONUÇ}

$\mathrm{Bu}$ çalışmada Glikoz oleat ve glikoz laurat sentezlenmiş ve bitkisel bazlı yenilebilir yağlar üzerindeki termal bozunma engelleyici özelliklerini araştırmak için karakterize edilmiştir. Yenilebilir yağlarınyağ asidibileşimleriGC kullanılarak belirlenmiş ve Glikoz laurate ve Glikoz oleatın, yenebilir yağların termal bozunması için bir oksidasyon inhibitörü olarak kullanılabileceği sonucuna varılmıştır. Glikoz oleat,

\section{KAYNAKLAR}

Addis P B, Warner G J, 1991. In Free Radicals and Food Additives, eds 0. I. Aruoma \& B. Halliwell. Taylor and Francis Ltd, London, 77.

Akin M, Arabaci G, Saki N, 2013. Total phenols, antioxidant potential and tyrosinase inhibitory activity of walnut (Juglans regia L.) leaf, husk and seed. Asian Journal of Chemistry, 25(16); 9337-9340.

Allen DK, Tao BY, 2002. Synthesis and Characterization of Maltose Fatty Acid Monoesters as Biosurfactants. Journal of surfactants and detergents, 5: 245-255.

AOCS (1993), Official Methods and Recommended Practices of the American Oil Chemists' Society, American Oil Chemists Society, Chicago, IL.

Aoshima H, Miyagisnima A, Nozawa Y, Sadzuka Y, Sonobe T, 2005. Glycerin fatty acid esters as a new lubricant of tablets. International Journal of Pharmaceutics, 293: 25-34.

Awasthi SK, 2000. Definition of standards of quality. In J. P. Bhatnagar (Ed.), Book prevention of food adulteration act with rules (3rd ed., pp. 699-700). New Delhi, India: Ashoka Law House, 707.

Choe YO, Min DB, 2005. Chemistry and reactions of reactive oxygen species in foods. Journal of Food Science, 70(9): 142-159.

Erickson SK, Matsui SM, Strewsbury MA, Coopre AD, Gordon R, 1978. Effects of 25-hydroxycholesterol and rat hepatic 3-hydroxy-3methylglutaryl coenzyme A reductase activity in vivo in perfused liver and hepatocytes. J. Biol. Chem, 253: 4159-4164.

Frankel EN, 1993. In search of better methods to evaluate natural antioxidants and oxidative stability in food lipids. Trends in Food Sci. Technol., 4: 220-225.

Furukawa S, Akiyoshi K, O’Tool GA, Ogihara G, Morinaga Y, 2010. Sugar fatty acid esters inhibit biofilm formation by food-borne pathogenic bacteria. International Journal of Food Microbiology, 138: 176-180.

Ghafoorunissa SH, 2007. Sesame lignans enhance the thermal stability of edible vegetable oils. Food chemistry, 105: 1076-1085.

Gunstone FD, 2000. Composition and properties of edible oils, in Edible Oil Processing (eds W. Hamm and R.J. Hamilton). Sheffield Academic Press, Sheffield, 1-33.

Hemalatha S, Ghafoorunissa, 2007. Sesame lignans enhance the termel stability of edible vegitable oils. Food Chemistry, 105: 1076-1085.

Kaitaranta JK, 1992. Control of lipid oxidation in fish oil with various antioxidative compounds. Journal of American Chemical Society, 69: 810-813.

Kays S, Teng Q, 1997. Characterization of Insecticidal Sugar Esters of Petunia. J. Agric. Food Chem, 45: 270-275.

Koski A, Pekkarinen S, Hopia Anu, Wahala K, Heinonen M, 2003. Precessing of rapeseed oil: effects on sinapic acid derivative content and oxidative stability. Eur. Food. Res. Technol., 217: 110-114. termal bozunmayı önleme amaçlı yenilebilir yağ katkısı olarak, uzun zincire sahip olmasından ötürü, Glikoz laurata göre çok daha iyi etki göstermiştir.

\section{TEŞEKKÜR}

$\mathrm{Bu}$ çalışma Kocaeli Üniversitesi Bilimsel Araştırma Projeleri tarafından desteklenmiştir. (Proje no: BAP-2016/071)

Lee J, Chung H, Chang P, Lee J, 2007. Development of a method the oxidative stability of edible oils using 2,2-diphenyl-1-picrylhydrazyl (DPPH). Food Chemistry, 103: 662-669.

Li Lu, Ji F, Wang J, Li Y, Bao Y, 2015. Esterification degree of fructose laurate exerted by Candida antarcticalipase B in organic solvents. Enzyme and Microbial Technology, 69: 46-53.

Maranesi M, Bochicchio D, Montellato L, Zaghini A, Pagliuca G, Badiani A, 2005. Effect of microwave cooking or broiling on selected nutrient contents, fatty acid patterns and true retention values in separable lean from lamb rib-loins, with emphasis on conjugated linoleic acid. Food Chemistry, 90: 207-218.

Molkentin J, 2009. Authentication of organic milk using d13C and the a-linolenic acid content of milk fat. Journal of Agricultural and Food Chemistry, 57: 785-790.

Rosa PM, Antoniassi R, Freitas SC, Bizzo HR, Zanotto DL, Oliveira MF, Castiglioni VBR, 2009. Chemical composition of Brazilian sunflower varieties. Helia, 32(50): 145-156.

Sakouhi F, Absalon C, Flamini G, Cioni PL, Kallel H, Boukhchina S, 2010. Lipid components of olive oil from Tunisian Cv. Sayali: Characterization and authenticity. ticity. Comptes Rendus Biologies. 333: 642-648.

Silva AC, Jorge N, 2012. Oxidative stability of soybean oil added to Lentinus edodes and Agaricus blazei mushromms extracts in an accelerated storage test. Nutrition\& Food Science, 42: 34-40.

Simic MG, Karel M, 1980. Autoxidation in Food and Biological Systems. Eds. Plenum Press, New York (USA).

St. Angelo AJ, 1992. Lipid Oxidation in Food. ACS Symposium Series, No 500, Ed. American Chemical Society, Washington (USA).

Tan CP, Che Man Y B, Selamat J, Yusoff MSA, 2002. Comparative studies of oxidative stability of edible oils by differential scanning calorimetry and oxidative stability index methods. Food Chemistry, 76: 385-389.

Von der Haar D, Stabler A, Wichmann R, Schwiggert-Weisz U, 2015. Enzymatic esterification of free fatty acid in vegetable oils utilizing different immobilized lipases, Biotechnol. Lett., 37: 169-174.

Yanishlieva NV, Marinova EM, 2001. Stabilisation of edible oils with natural antioxidants. Eur. J. Lipid Sci. Technol., 103: 752-767.

Zeb A, Murkovic M, 2013. Pro-oxidant effects of b-carotene during thermal oxidation of edible oils. J. Am. Oil Chem. Soc., 90: 881-889.

Zhang Y, Yang L, Zu Y, Chen X, Wang F, Liu F, 2010. Oxidative stability of sunflower oil supplemented with carnosic acid compared with synthetic antioxidants during accelerated storage. Food Chemistry, 118(3); 656-662.

Zhao L, Zhang H, Hao T, Li S, 2015. In vitro antibacterial activities and mechanism of sugar fatty acid esters against five food-related bacteria. Food chemistry, 187: 370-377. 